\title{
SPECIALISATION IN AGRICULTURAL AND FOOD EXPORTS OF LITHUANIA
}

\section{Jolanta Droždz}

\author{
Faculty of Economics and Business Administration, Vilnius University, Vilnius, Lithuania \\ E-mail: jolanta.drozdz@cr.vu.lt
}

\begin{abstract}
The analysed research problem answer the question of how the changing trade conditions affect Lithuanian agricultural and food exports. The paper aims to assess the level of specialization in the agricultural and food sector exports of Lithuania. Assessment of the level of specialization was based on calculation of the trade coverage, revealed comparative advantage and intra-industry trade indices and their aggregation. Empirical research covers the period of 1999-2014. The export of agricultural and food products of Lithuania has been positively affected by trade liberalisation and achieved the effect of synergy due to regional integration processes (membership in the EU). It is characterised by high level of specialisation; nevertheless, this does not contribute to increasing of added value in agriculture.
\end{abstract}

Keywords: agricultural and food exports, specialisation, trade coverage, comparative advantage, intraindustry trade.

JEL Classification: F15, F40, F41, N50, Q17.

\section{Introduction}

After the restoration of independence in 1991, the reforms have essentially changed the economic relations of Lithuania with the rest of the world. Signing free trade agreements with many countries, creating conditions for free movement of capital to and from Lithuania, joining the World trade organisation (WTO) and the European Union (EU) allows us to assert that Lithuania has become an open economy. The development of foreign trade, especially exports, is one of important factors for economic growth in the small open economies. Structural changes, i.e. long-run changes in the agriculture-manufacturing-services-structure, are a key property of growth and development processes with massive impacts on economy and society and are part of actual debates regarding policy in developing and developed economies (Stijepic \& Wagner, 2018). The structure of a country's economy is the key factor that distinguishes successful countries from the unsuccessful ones and is of vital importance for economic growth (Lankauskienè \& Tvaronavičienè, 2013). The impacts of intermediate trade on sector structure depend on three factors: productivity gains from trade, specialisation in international trade and development stage (Stijepic \& Wagner, 2018). The first and foremost of such a critical importance is that a small economy, as a rule, does not have enough resources to produce a wide range of goods and services in order to meet domestic consumption and investment needs. Therefore, in order to bring the desired products, the country must be able to offer to foreign markets certain goods and services for which the necessary imports could be financed.

The analysed research problem helps to answer the question of how the changing trade conditions affect Lithuanian agricultural and food exports. The paper aims to assess the level of specialization in the agricultural and food sector exports of Lithuania during the long time period from 1999 up to 2014. The main tasks for achieving the goal include a comprehensive literature review in determination the level of specialisation; selection of methods for further analysis and provision of the aggregated approach on the measurement of the specialisation level in exports of agricultural and food products of Lithuania in empirical terms.

\section{Literature review}

Representatives of all economic theories were united in terms of the concept of competitiveness, which was understood as the country's ability to export. However, low cost and price competition is decreasing, it remains dominant in those sectors where the main factors of production are natural resources and low-skilled labor, which is relevant to the agricultural and food sector. 
The exports of agricultural and food products of Lithuania is best reflected in its international performance. The topic of specialization in scientific sources has an important place, since the level of specialization depends on further economic development of the country (Bernatonyte, 2011; Droždz \& Miškinis, 2011; Bernatonyte, Burkšaitienè, \& Rimienè, 2013; Šidlauskaite \& Miškinis, 2013; Bojnec \& Fertő, 2014; Pilinkienè, 2014; Serva \& Vitunskienè, 2014; Travkina \& Tvaronavičienè, 2015).

Specialisation studies compose the core of international trade theory. Countries were not obliged in being self-sufficient in all the groups of the products, instead of that, can specialize in the production of certain goods, increase labor productivity and efficiency in selected sectors. Many studies show that more developed countries are more specialized in international trade.

Foreign authors tend to deeply analyze country specialisation (Bojnec \& Fertő, 2014; Pohlová \& Mezera, 2014; Taneja \& Wani, 2014; Wyszkowska-Kuna, 2014; Couillard \& Turkina, 2015; Idris, Singh, \& Praveen, 2015; Laursen, 2015; Siddique, Sen, \& Srivastava, 2016) and highlight the problem of intra-industry trade (Amighini, Leone, \& Rabellotti, 2011; Ferrarini \& Scaramozzino, 2011; Ambroziak, Bułkowska, \& Szczepaniak, 2014; Molendowski, 2014; Kumar \& Ahmed, 2015). Intra-industry trade refers to the exchange of similar products belonging to the same industry. The term is usually applied to international trade, where the same types of goods or services are both imported and exported.

The case of the development of international trade in Lithuania is widely discussed in the scientific literature. The scientific literature focuses on the topics of competitiveness and specialization in exports and the assessment of the impact of exports on the economy (Bernatonyte, 2011; Kalendienè \& Miliauskas, 2011; Sabonienè, 2011; Travkina \& Tvaronavičienè, 2011; Bruneckienè \& Paltanavičienè, 2012; Grebliauskas \& Stonys, 2012; Notten, 2012; PetrauskaitèSenkevič, 2012; Bernatonytė et al., 2013; Langvinienè \& Sekliuckienè, 2012; Šidlauskaitė \& Miškinis, 2013; Bojnec \& Fertő, 2014; Kalendienė, 2014; Pilinkienè, 2014; Serva \& Vitunskienè, 2014; Droždz \& Volkov, 2015; Travkina \& Tvaronavičienè, 2015; Zacharevič \& Dzemyda, 2015).

But still, there is a lack of systematic approach, which covers all three important questions on the measurement of the "real" level of special- isation in agricultural and food exports of Lithuania, such as revealed comparative advantage and intra-industry trade performance.

Revealed Comparative Advantage index (RCA) is the most common indicator used for the assessment of the level of specialisation in trade, but still has lots of inconsistencies, so it is performed in different forms (see Table 1). Within the field of international trade, the subject of intraindustry trade has been discussed less scientific literature. Table 1 performs the indices of intraindustry trade measurement.

Table 1. Indices of specialisation measurement in scientific literature (source: own contribution)

\begin{tabular}{|c|c|c|c|c|c|}
\hline \multirow{2}{*}{$\begin{array}{l}\text { Authors/ } \\
\text { Indices* }\end{array}$} & \multicolumn{5}{|c|}{$\begin{array}{c}\text { Indices of specialisation } \\
\text { measurement }\end{array}$} \\
\hline & RCA & RCAi & RSCA & RMA & RTA \\
\hline $\begin{array}{l}\text { Ambroziak } \\
\text { et al., } 2014\end{array}$ & + & & & & \\
\hline $\begin{array}{l}\text { Bernatonyte } \\
\text { et al., } 2013\end{array}$ & + & & & & + \\
\hline $\begin{array}{l}\text { Bojnec and } \\
\text { Fertö, } 2014\end{array}$ & + & & & & \\
\hline $\begin{array}{l}\text { Couillard } \\
\text { and Turkina, } \\
2015\end{array}$ & + & & & & \\
\hline $\begin{array}{l}\text { Droždz and } \\
\text { Miškinis, } \\
2011\end{array}$ & + & & & & \\
\hline $\begin{array}{l}\text { Ferrarini and } \\
\text { Scaramoz- } \\
\text { zino, } 2011\end{array}$ & + & & & & \\
\hline $\begin{array}{l}\text { Idris et al., } \\
2015\end{array}$ & + & & & & \\
\hline $\begin{array}{l}\text { Kumar and } \\
\text { Ahmed, } \\
2015\end{array}$ & + & & & & \\
\hline $\begin{array}{l}\text { Pilinkienè, } \\
2014\end{array}$ & + & & & + & + \\
\hline $\begin{array}{l}\text { Pohlová and } \\
\text { Mezera, } \\
2014\end{array}$ & + & & & & \\
\hline $\begin{array}{l}\text { Sabonienè, } \\
2011\end{array}$ & + & + & + & & \\
\hline $\begin{array}{l}\text { Serva and } \\
\text { Vitunskiené, } \\
2014\end{array}$ & + & & & & \\
\hline $\begin{array}{l}\text { Siddique } \\
\text { et al., } 2016\end{array}$ & + & & & & \\
\hline $\begin{array}{l}\text { Taneja and } \\
\text { Wani, } 2014\end{array}$ & + & & & & \\
\hline $\begin{array}{l}\text { Wyszkows- } \\
\text { ka-Kuna, } \\
2014\end{array}$ & + & & & & \\
\hline
\end{tabular}


End of Table 1

\begin{tabular}{|l|c|c|c|c|c|}
\hline & \multicolumn{5}{|c|}{$\begin{array}{c}\text { Indices of intra-industry trade } \\
\text { measurement }\end{array}$} \\
\hline & GLI & LFI & TCI & MIIT & - \\
\hline $\begin{array}{l}\text { Ambroziak } \\
\text { et al., 2014 }\end{array}$ & & + & + & & \\
\hline $\begin{array}{l}\text { Bernatonyte } \\
\text { et al., 2013 }\end{array}$ & + & & & & \\
\hline $\begin{array}{l}\text { Miškinis and } \\
\text { Dultsau, } \\
2012\end{array}$ & & & + & & \\
\hline $\begin{array}{l}\text { Saboniene, } \\
\text { 2011 }\end{array}$ & & + & & & \\
\hline $\begin{array}{l}\text { Kumar and } \\
\text { Ahmed, } \\
\text { 2015 }\end{array}$ & & & + & + & \\
\hline $\begin{array}{l}\text { Molendows- } \\
\text { ki, 2014 }\end{array}$ & + & & & & \\
\hline $\begin{array}{l}\text { Ferrarini and } \\
\text { Scaramo- } \\
\text { zzino, 2011 }\end{array}$ & + & + & & & \\
\hline
\end{tabular}

* RCA - revealed comparative advantage; $\mathrm{RCAi}$ - revealed comparative advantage in imports; RSCA - Revealed symmetric comparative advantage; RMA - relative import advantage index; RTA - relative trade advantage index; GLI Grubel-Lloyd index; LFI - Lafay index; TCI - Trade coverage index; MIIT - Marginal Intra-Industry Trade Index.

While RCA overestimates the import flows in the same product group, so it has to be supplemented with intra-industry trade assessment. For this purpose Grubel-Lloyd index (GLI), Lafay index (LFI), Trade coverage index (TCI) and Marginal Intra-Industry Trade Index (MIIT) are used in the scientific literature. As complementary ones, RCA, TCI and LFI are chosen for further analysis. Classic interpretation for RCA is used.

The use of GLI index present some problem. It is a static measure of the intra-industry trade and it measures the share of intra-industry trade at the point of time. It fails to capture the dynamic contribution by intra-industry trade over a period of time when the volume of total trade is not static. It shows increase in the volume of trade rather than the increase in intra-industry trade.

The complex system of country sector specialization assessment methods integrating the aspects of specialization and intra-industry trade is determined by the three main indicators for the calculation of specialization level: RCA - Revealed Comparative Advantage index, TCI Trade Coverage index and LFI - Lafay index. The proposed system of investigative techniques makes it possible to identify the sub-sectors of competitive advantage, eliminating excessive flows of international trade.

\section{Methods}

Reflecting on the literature review, assessment of the level of specialization based on calculation of the RCA, TCI and LFI and their aggregation. Empirical research covers the period of 1999-2014.

The level of specialization in agricultural and food exports calculated with RCA. Revealed comparative advantage concept often used to identify country's weaknesses and strengths in particular industries or sectors. Index calculation based on international trade structural indicators. The relatively higher share of the country's export markets reveals its Comparative advantage, and vice versa, the relatively lower value shows that the country has a Comparative disadvantage (Balassa, 1965):

$$
B_{i j}=\frac{X_{i j} / X_{r j}}{X_{i s} / X_{r s}}
$$

where, $X$ - exports; $i$-good; $j$ - country; $r$ - group of goods; $s$-group of countries.

However, RCA index underestimate the import flows in the same product group. For this purpose, it is suggested to complement analysis with additional indexes - Trade coverage index (TCI) and Lafay index (LFI) for intra-industry trade analysis (Lafay, 1992). TCI represented by formula:

$$
\mathrm{TCI}=X_{a} / M_{a} \times 100 \%,
$$

where, $X_{a}$-agricultural and food product exports, $M_{a}$ - agricultural and food product imports.

TCI complements the study with the exportimport ratio, which indicates how much export revenues cover the cost of imports. When the TCI excess the 100 per cent, the country has a surplus in international trade in a particular product group, and vice versa, if the TCI is less than 100 percent a trade deficit captured in the certain group of products. TCI shows a narrower range of globally competitive agricultural and food products, as it eliminates re-export flows and particular product groups, which perform the negative trade balance.

Theoretical and empirical research emphasize intra-industry importance in international trade (Ferrarini \& Scaramozzino, 2011; Sabonienè, 2011; Miškinis \& Dultsau, 2012; Bernatonytė et al., 2013; Ambroziak et al., 2014; Molendowski, 2014; Kumar \& Ahmed, 2015). High export and import flows of intra-industry trade partly explain the horizontal product differentiation. LFI formula is as follows: 


$$
\begin{aligned}
& L F I_{j}=100\left(\frac{x_{j}-m_{j}}{x_{j}+m_{j}}-\frac{\sum_{j=1}^{N}\left(x_{j}-m_{j}\right)}{\sum_{j=1}^{N}\left(x_{j}+m_{j}\right)}\right) \times \\
& \frac{x_{j}+m_{j}}{\sum_{j=1}^{N}\left(x_{j}+m_{j}\right)},
\end{aligned}
$$

where, $j$ - sector, $X$ - exports, $M$ - imports.

In other words, it is:

$L F I_{j}=100 \times($ sector trade balance - total trade balance)/sector share in total trade.

If $L F I$ value $>0$, country has a comparative advantage, if $L F I$ value $<0$, country has a comparative disadvantage in international trade. $L F I$ index for intra-industry analysis provides deeper analysis on competitive advantage of Lithuanian agricultural and food products, because it assessed export import ratio, when the overall trade is balanced.

The proposed system of investigative techniques makes it possible to identify the sub-sectors of competitive advantage and level of specialisation in particular sub-sectors, eliminating excessive flows of international trade.

The values of all three indices are aggregated into a common result. The two most important cases of export development are the existence of a competitive export advantage for all indexes $(+++)$ and the second option, where there is no competitive advantage for all indices (---). In the first case, TCI $>100 \%$, LFI $>0$, RCA $>1$. In the second case, $\mathrm{TCI}<100 \%$, LFI $<0, \mathrm{RCA}<1$, as suggested by Ambroziak et al. (2014).

Volumes of export and import of Lithuanian agricultural and food products, trade balance and their dynamics during the fifteen years (19992014) period, according to the double-digit level of the Combined Nomenclature $(\mathrm{CN})$, were used for the calculations. The data from Lithuanian Department of Statistics and the United Nations International Trade Database (UN Comtrade) was used (on aggregated and split level) on sectoral scope (CN 01-24).

\section{Results}

Analysis of the international trade of Lithuanian agricultural and food products divided into three phases. The first period covers the years from 1999 to 2003 (from the earliest available comparable statistics until the year before Lithuania's accession to the EU). The second period covers the years from 2004 to 2008 (trade peak since joining the EU by 2008 the global economic crisis). In addition, the third period includes years 2009-2014 (recovery after the crisis period).
Agricultural and food product exports in 1999-2003, have been in certain stagnation and foreign trade in agricultural and food balance was negative. Since 2004, agricultural and food product exports gained momentum and began to grow rapidly, reaching a value of 4644 million EUR in 2014. Lithuanian agricultural and food exports value increased twice from 2009 to 2014 . Over the lifetime of the EU membership, this indicator increased by more than five times in 2014 compared to 2004. Agricultural and food imports grew at a slower rate during the same period, although it increased and reached its value of 3706 million EUR in 2014. It was more than 4 times higher than in 2004. International trade in agricultural and food products balance reached a record of 939 million EUR in 2014, in other words, a one fifth of the total agricultural and food exports.

Lithuanian origin agricultural and food products throughout the agricultural and food product exports accounted for 90 percent in 1999. This tendency preserved up to the accession to the EU. Later it began to decline, and counted only 65 percent in 2014. It was obvious that Lithuania has become the gateway from the West to the East for the agricultural and food exports.

The assessment of Lithuanian origin exports reveals alarming trend of rapidly increasing share of primary agricultural commodities and the exports of processed food products falling. This tendency became apparent after 2008. It may be partly explained by the increasing grain harvest and relatively easy and fast realization of it on the world market. However, in the long run this trend persists, it is necessary to analyse the details of exports of Lithuanian origin agricultural and food products and to clarify the relationship between the reasons why these processes take place.

Assessing the sectoral point of view there was a lot of structural changes in agricultural and food product exports during the analysed period. Livestock products dominated in the export structure by the Lithuanian membership in the EU. This trend reversed in favour of the plant products since 2004. The main exported agricultural and food products from Lithuania to the world were dairy products, tobacco and cereals in 2003. These three groups accounted for almost half of the total Lithuanian agricultural and food exports. Lithuanian agricultural and food export structure become more diversified in 2014. Four main exported agricultural and food products from Lithuania to the world were milk and milk products, eggs and honey; cereals; edible fruits and 
nut; and edible vegetables. These groups accounted for about 44 per cent of the total Lithuanian agricultural and food exports.

Table 2. RCA index values of agricultural and food product exports of Lithuania in years 1999, 2004, 2009 and 2014 (source: own calculations)

\begin{tabular}{|c|c|c|c|c|}
\hline $\begin{array}{c}\mathrm{CN} \\
\text { code }\end{array}$ & 1999 & 2004 & 2009 & 2014 \\
\hline 01 & 1.26 & 1.52 & 5.77 & 3.56 \\
\hline 02 & 0.64 & 0.60 & 1.46 & 1.35 \\
\hline 03 & 0.65 & 1.18 & 1.63 & 1.5 \\
\hline 04 & 7.43 & 6.39 & 6.04 & 5.22 \\
\hline 05 & 1.49 & 0.77 & 0.64 & 0.54 \\
\hline 06 & 0.08 & 0.18 & 0.63 & 0.75 \\
\hline 07 & 1.43 & 1.40 & 2.86 & 3.21 \\
\hline 08 & 0.78 & 0.77 & 3.08 & 3.31 \\
\hline 09 & 0.73 & 0.51 & 0.84 & 0.87 \\
\hline 10 & 1.65 & 1.93 & 3.33 & 3.14 \\
\hline 11 & 0.64 & 1.37 & 4.28 & 4.30 \\
\hline 12 & 2.39 & 1.20 & 1.73 & 1.78 \\
\hline 13 & 0.04 & 0.11 & 0.41 & 0.43 \\
\hline 14 & 0.11 & 0.25 & 0.19 & 0.09 \\
\hline 15 & 0.34 & 0.56 & 0.70 & 0.32 \\
\hline 16 & 2.62 & 2.95 & 4.49 & 4.03 \\
\hline 17 & 0.89 & 1.93 & 1.45 & 1.18 \\
\hline 18 & 1.42 & 1.55 & 1.72 & 1.38 \\
\hline 19 & 0.19 & 0.65 & 1.37 & 1.17 \\
\hline 20 & 0.74 & 0.60 & 0.75 & 0.51 \\
\hline 21 & 2.13 & 1.18 & 2.01 & 1.93 \\
\hline 22 & 0.24 & 0.31 & 1.22 & 1.65 \\
\hline 23 & 3.59 & 4.49 & 3.72 & 2.92 \\
\hline 24 & 2.24 & 1.94 & 4.08 & 4.31 \\
\hline
\end{tabular}

RCA index (see Table 2) highlighted the comparative advantage of Lithuanian agricultural and food sector.

RCA index shows that Lithuania has a strong comparative advantage $(\mathrm{RCA}>2)$ in live animals (CN 01), milk and dairy products (CN 04), edible vegetables $(\mathrm{CN} 07)$ and fruits $(\mathrm{CN} 08)$, cereals (CN 10), products of the milling industry (CN 11), preparations of meat, fish or crustaceans etc. (CN 16), residues and waste from the food industries and prepared animal fodder (CN 23), tobacco and manufactured tobacco substitutes (CN 24) exports. According to the results growth trend observed in the level of specialization in milling production, production of meat and fish, and tobacco exports. The groups $\mathrm{CN}$ 07-08 represent mostly re-exports.
Table 3. TCI values of agricultural and food product exports of Lithuania in in years 1999, 2004, 2009 and 2014 (source: own calculations)

\begin{tabular}{|c|c|c|c|c|}
\hline $\begin{array}{l}\mathrm{CN} \\
\text { code }\end{array}$ & 1999 & 2004 & 2009 & 2014 \\
\hline 01 & 2.81 & 2.43 & 5.10 & 1.91 \\
\hline 02 & 0.68 & 0.46 & 0.75 & 1.16 \\
\hline 03 & 0.28 & 0.65 & 0.58 & 0.90 \\
\hline 04 & 9.94 & 14.52 & 4.41 & 2.12 \\
\hline 05 & 0.25 & 0.17 & 0.16 & 0.41 \\
\hline 06 & 0.08 & 0.18 & 0.48 & 0.96 \\
\hline 07 & 0.80 & 0.86 & 0.93 & 0.92 \\
\hline 08 & 0.08 & 0.30 & 0.76 & 0.76 \\
\hline 09 & 0.05 & 0.19 & 0.36 & 0.48 \\
\hline 10 & 3.90 & 3.68 & 12.75 & 8.45 \\
\hline 11 & 0.19 & 0.62 & 3.75 & 3.43 \\
\hline 12 & 1.35 & 1.38 & 1.91 & 2.21 \\
\hline 13 & 0.02 & 0.11 & 0.37 & 0.50 \\
\hline 14 & 0.79 & 0.56 & 0.95 & 0.28 \\
\hline 15 & 0.08 & 0.28 & 0.45 & 0.49 \\
\hline 16 & 1.52 & 3.08 & 2.68 & 2.16 \\
\hline 17 & 0.58 & 0.68 & 0.83 & 1.55 \\
\hline 18 & 0.86 & 1.10 & 1.06 & 1.05 \\
\hline 19 & 0.06 & 0.51 & 0.95 & 1.28 \\
\hline 20 & 0.23 & 0.41 & 0.54 & 0.56 \\
\hline 21 & 0.22 & 0.37 & 0.73 & 0.96 \\
\hline 22 & 0.10 & 0.22 & 0.53 & 0.82 \\
\hline 23 & 1.50 & 1.95 & 1.83 & 1.25 \\
\hline 24 & 0.50 & 1.34 & 1.35 & 2.09 \\
\hline
\end{tabular}

The selected TCI index shows the export / import ratio, which indicates how much export revenues cover import costs. The TCI reflects a narrower world-wide range of competitive agricultural and food products, since eliminating reexports and those product groups for which a negative trade balance is calculated (see Table 3 ).

LFI shows the export / import ratio when all trade is balanced. Positive LFI values and sustainable long term competitive advantage obtained in just a few groups of agricutural and food exports of Lithuania (see Table 4).

The aggregation of the individual indices is presented in Table 5, where the results attained a certain competitive advantage, specialization positions in the international market of Lithuanian agricultural and food products. As already mentioned in the methodology, the RCA index reflects the country's ability to export, the TCI includes export and import flows, indicating the international trade balance of individual product groups, 
and the LFI determines the volume of intra-industry trade.

Table 4. LFI values of agricultural and food product exports of Lithuania in in years 1999, 2004, 2009 and 2014 (source: own calculations)

\begin{tabular}{|c|c|c|c|c|}
\hline $\begin{array}{c}\mathrm{CN} \\
\text { code }\end{array}$ & 1999 & 2004 & 2009 & 2014 \\
\hline 01 & 0.67 & 0.48 & 1.53 & 0.24 \\
\hline 02 & 0.10 & -1.94 & -1.62 & -0.20 \\
\hline 03 & -2.10 & -1.55 & -2.47 & -1.32 \\
\hline 04 & 15.21 & 12.30 & 5.23 & 2.57 \\
\hline 05 & -0.43 & -0.87 & -0.56 & -0.27 \\
\hline 06 & -0.41 & -0.52 & -0.35 & -0.32 \\
\hline 07 & 0.42 & -0.34 & -0.82 & -1.23 \\
\hline 08 & -4.37 & -3.66 & -2.40 & -2.66 \\
\hline 09 & -3.11 & -1.69 & -1.23 & -1.00 \\
\hline 10 & 3.56 & 3.09 & 4.87 & 5.40 \\
\hline 11 & -0.65 & -0.36 & 0.81 & 0.68 \\
\hline 12 & 1.42 & 0.48 & 0.77 & 0.56 \\
\hline 13 & -0.09 & -0.14 & -0.08 & -0.13 \\
\hline 14 & 0.00 & 0.00 & 0.00 & 0.00 \\
\hline 15 & -3.29 & -2.64 & -1.60 & -1.36 \\
\hline 16 & 0.86 & 2.17 & 1.75 & 0.68 \\
\hline 17 & -0.09 & -0.91 & -0.44 & 0.20 \\
\hline 18 & 0.32 & 0.14 & -0.16 & -0.23 \\
\hline 19 & -1.32 & -0.83 & -0.34 & 0.04 \\
\hline 20 & -1.92 & -1.22 & -0.87 & -0.67 \\
\hline 21 & -2.87 & -2.67 & -1.15 & -0.54 \\
\hline 22 & -3.59 & -2.98 & -2.51 & -1.96 \\
\hline 23 & 2.79 & 3.08 & 1.35 & -0.01 \\
\hline 24 & -1.09 & 0.57 & 0.31 & 1.55 \\
\hline
\end{tabular}

Analysis showed that globally competitive, with a stable position on the world market agricultural and food products groups are as follows: CN01 live animals; CN04 milk and milk products; CN10 cereals; CN11 milling products; CN12 Oil seeds and oleaginous fruits; CN16 Preparations of meat, fish or crustaceans and CN24 tobacco and manufactured tobacco substitutes.

Three agricultural and food product groups (CN10 cereals, CN11 milling production and CN24 tobacco and manufactured tobacco substitutes) demonstrate the growth of the all indices. Thesis found that animal origin products lose their competitive advantage in favour of plant origin products. It is assumed that the EU direct support to crop production sector affects not only the production process, but also changed the export structure of the country's competitive potential on the international market.
Table 5. Aggregation of TCI, RCA, LFI indices in years 1999, 2004, 2009 and 2014 of agricultural and food exports of Lithuania* (source: own calculations)

\begin{tabular}{|c|c|c|c|c|}
\hline $\begin{array}{c}\mathrm{CN} \\
\text { code }\end{array}$ & 1999 & 2004 & 2009 & 2014 \\
\hline 01 & +++ & +++ & +++ & +++ \\
\hline 02 & --+ & --- & -+- & ++- \\
\hline 03 & --- & -+- & -+- & -+- \\
\hline 04 & +++ & +++ & +++ & +++ \\
\hline 05 & -+- & --- & --- & --- \\
\hline 06 & --- & --- & --- & -+- \\
\hline 07 & -++ & -+- & -+- & -+- \\
\hline 08 & --- & --- & -+- & -+- \\
\hline 09 & --- & --- & --- & -+- \\
\hline 10 & +++ & +++ & +++ & +++ \\
\hline 11 & --- & -+- & +++ & +++ \\
\hline 12 & +++ & +++ & +++ & +++ \\
\hline 13 & --- & --- & --- & -- \\
\hline 14 & --- & --- & --- & --- \\
\hline 15 & --- & --- & --- & --- \\
\hline 16 & +++ & +++ & +++ & +++ \\
\hline 17 & ++- & -+- & -+- & +++ \\
\hline 18 & -++ & +++ & ++- & ++- \\
\hline 19 & --- & --- & -+- & +++ \\
\hline 20 & --- & --- & --- & --- \\
\hline 21 & -+- & -+- & -+- & -+- \\
\hline 22 & --- & --- & -+- & -+- \\
\hline 23 & +++ & +++ & +++ & ++- \\
\hline 24 & -+- & +++ & +++ & +++ \\
\hline
\end{tabular}

*"++" if TCI $>1$; " +" if $\mathrm{RCA}>1$; " +" if $\mathrm{LFI}>0$.

Exports of live animals and cereals make it more fearful than enjoying a comparative advantage. Lithuania loses added value. The capacities of slaughterhouses and meat processing companies, technical equipment on farm level are not fully used, while large amounts of EU support and private capital invested in these facilities. In the dairy product group, Lithuania specializes in exporting cheeses and curd. These products are of higher value added. In these case, as well, as in the next product group of meat products, Lithuania exports a semi-processed agricultural products.

\section{Discussion}

Specialisation in international trade in agricultural and food products should be developed alongside with diversification processes at the product level and geographically. It is recommended for exporters to extend the diversification on product level. 
It is recommended to orient the national and EU financial support to the creation of higher value-added products in agricultural and food sector, development of animal husbandry, organic farming sector, supporting the production of the niche products. Thus, the leverage of non-processed crop products in the total exports of agricultural and food products of Lithuania would be reduced.

\section{Conclusions}

As for crop products, the export of cereal is most important, meanwhile, as for livestock products, the export of milk and milk products is most important. In the first case, raw products are exported, in the second case, processed products creating added value are exported. In the course of the research, it has been determined that the trade inside the branch prevails in international trade in the Lithuanian agricultural and food products, since the agricultural sector is an important source of raw materials.

The growing export of the milling industry products is considered as a positive trend and as leverage for the export of high quality cereal. Poorer quality cereals could be used as a feedstuff and, thus, contribute to animal husbandry development in Lithuania. The balance is disturbed by the direct EU support for crop production, the scope of which is disproportionately higher than the support to animal husbandry.

As Lithuania has no powers in formation of the international commercial policy, it should take care of increasing the domestic competitiveness of the agricultural sector and the restrictions arising out of application of the EU common agricultural policy should be compensated by applying effective diplomatic and management decisions.

\section{Further research area}

It is recommended to assess the impact of different domestic support measures of the EU Common agricultural policy on the export of agricultural and food products of the Lithuanian origin in further research because the impact of the aforementioned measures on the structure of production of agricultural and food products is evident. The main factors that may influence the export of the Lithuanian agricultural and food products are direct support and/or investment support to agriculture.
The scientific literature lacks methodologically sound and practically applicable competitiveness index of separate sectors which allows comparing different countries. This presupposes the directions of further research.

\section{Disclosure statement}

Author do not have any competing financial, professional, or personal interests from other parties.

\section{References}

Ambroziak, Ł., Bułkowska, M., \& Szczepaniak, I. (2014). Assessment of the competitiveness of Polish food producers in the European Union. Research paper (136 p.).

Amighini, A., Leone, M., \& Rabellotti, R. (2011). Persistence versus change in the international specialization pattern of Italy: how much does the 'district effect' matter?. Regional Studies, 45, 381-401. https://doi.org/10.1080/00343401003604655

Balassa, B. (1965). Trade liberalization and revealed comparative advantage. The Manchester School of Economics and Social Sciences, 33, 35-55.

Bernatonyte, D. (2011). Export productivity and specialization patterns of Lithuania. Economics \& Management, 16, 109-115.

Bernatonytė, D., Burkšaitienè, D., \& Rimienè, K. (2013). Trade specialization pattern of Lithuania. Economics \& Management, 18(4), 661-665.

Bojnec, Š., \& Fertő, I. (2014). Export competitiveness of dairy products on global markets: the case of the European Union countries. Journal of Dairy Science, 97(10), 6151-6163.

https://doi.org/10.3168/jds.2013-7711

Bruneckienė, J., \& Paltanavičienè, D. (2012). Measurement of export competitiveness of the Baltic states by composite index. Engineering Economics, 23(1), 50-62.

Couillard, C., \& Turkina, E. (2015). Trade liberalisation: the effects of free trade agreements on the competitiveness of the dairy sector. World Economy, 38(6), 1015-1033. https://doi.org/10.1111/twec.12181

Droždz, J., \& Miškinis, A. (2011). Rusijos, Baltarusijos ir Kazachstano muitų sajungos žemès ūkio ir maisto produktų santykinio pranašumo vertinimas. Pinigu studijos, 15(2), 24-40.

Droždz, J., \& Volkov, A. (2015). Food market diversification approach - Lithuanian case. Zagadnienia Ekonomiki Rolnej, 343(2), 61-71. https://doi.org/10.5604/00441600.1152133

Ferrarini, B., \& Scaramozzino, P. (2011). Indicators and patterns of specialization in international trade. NCCR Trade Working Paper, 10, 1-43.

Grebliauskas, A., \& Stonys, M. (2012). Lietuvos pramonès eksporto konkurencingumo vertinimas. Taikomoji ekonomika: sisteminiai tyrimai, 6(2), 49-72. https://doi.org/10.7220/AESR.1822.7996.2012.6.2.3

Idris, S., Singh, A., \& Praveen, K. V. (2015). Trade competitiveness and impact of food safety regulations on market access of India's horticultural trade. Agricultural Economics Research Review, 28(2), 301-309. https://doi.org/10.5958/0974-0279.2016.00009.4 
Kalendienè, J. (2014). Assessment of Lithuanian export competitiveness in EU market. Taikomoji ekonomika: sisteminiai tyrimai, 8(1), 67-77. https://doi.org/10.7220/AESR.1822.7996.2014.8.1.4

Kalendienè, J., \& Miliauskas, G. (2011). Lithuania export competitiveness before economic recession. Business and Economic Horizons, 4(1), 40-51. https://doi.org/10.15208/beh.2011.4

Kumar, S., \& Ahmed, S. (2015). Intra-industry trade and trade complementarity: evidence from India-Sri Lanka bilateral trade. Journal of International Economics, $6(2), 38-70$.

Lafay, G. (1992). The measurement of revealed comparative advantage. In M. G. Dagenais \& P. A. Muet (Eds.), International trade modelling. London: Chapman \& Hall. https://doi.org/10.1007/978-1-4757-2150-8 10

Langvinienè, N., \& Sekliuckienè, J. (2012). Latecomer countries' international trade in services: the case of Lithuania. Economics \& Management, 17(2), 534-540. https://doi.org/10.5755/j01.em.17.2.2178

Lankauskienè, T., \& Tvaronavičienè, M. (2013). Economic sector performance and growth: contemporary approaches in the context of sustainable development. Intellectual economics, 7(3), 355-374. https://doi.org/10.13165/IE-13-7-3-07

Laursen, K. (2015). Revealed comparative advantage and the alternatives as measures of international specialization. Eurasian Bussiness Review, 5, 99-115. https://doi.org/10.1007/s40821-015-0017-1

Miškinis, A., \& Dultsau, I. (2012). Economic impacts of EUBelarusian trade. Ekonomika, 91(2), 49-65.

Molendowski, E. (2014). The visegrad group countries changes in intra-industry competitiveness of their economies during the world financial and economic crisis. Procedia-Social and Behavioral Sciences, 110, 1006-1013. https://doi.org/10.1016/j.sbspro.2013.12.947

Notten, T. E. H. (2012). The role of supply and demand factors for Lithuanian exports: an ARDL bounds testing approach. Pinigu studijos, 2, 2-39.

Petrauskaitè-Senkevič, L. (2012). Globalizacijos poveikis Lietuvos paukštininkystès sektoriui 2000-2010 metais. Management Theory \& Studies for Rural Business \& Infrastructure Development, 29(5), 135-146.

Pilinkienè, V. (2014). Evaluation of international competitiveness using the revealed comparative advantage indices: the case of the Baltic states. Mediterranean Journal of Social Sciences, 5(13), 353-359.
Pohlová, K., \& Mezera, J. (2014). Analysis of development of Czech foreign trade in foods and beverages. Agris On-Line Papers in Economics \& Informatics, 6(4), 121-131.

Saboniene, A. (2011). The changes of Lithuanian export competitiveness in the context of economic crisis. Ekonomika ir vadyba, 16, 302-308.

Serva, E., \& Vitunskienè, V. (2014). Shifts in pattern of specialisation of Lithuania's agri-food products export. Economic Science for Rural Development Conference Proceedings, 34, 135-144.

Siddique, M. A. B., Sen, R., \& Srivastava, S. (2016). Australia-Thailand trade: an analysis of competitiveness and effects of the bilateral FT. Journal of Developing Areas, 5(50), 103-118. https://doi.org/10.1353/jda.2016.0044

Stijepic, D., \& Wagner, H. (2018). Impacts of intermediate trade on sector structure. Journal of International Trade \& Economic Development, 27(1), 102-122. https://doi.org/10.1080/09638199.2017.1344725

Šidlauskaitė, B., \& Miškinis, A. (2013). Naujųjų ES šalių ūkio specializacija ekonominès integracijos kontekste. Ekonomika ir vadyba: aktualijos ir perspektyvos, 4, 5060.

Taneja, K., \& Wani, N. U. H. (2014). Economic performance of Indo-China merchandise trade: an analysis of RCA and RID approaches. Journal of International Economics, 5(1), 88-104.

Travkina, I., \& Tvaronavičienè, M. (2011). Export competitiveness and domestic productivity facets: case of Lithuania. Journal of business economics and management, 12(1), 49-68. https://doi.org/10.3846/16111699.2011.555360

Travkina, I., \& Tvaronavičienė, M. (2015). Peculiarities of export structure in Lithuania: synthesis and analysis. Entrepreneurship and Sustainability Issues, 2(4), 233247.

Wyszkowska-Kuna, J. (2014). Competitiveness in international trade in knowledge-intensive services - the case of Poland. Comparative Economic Research, 17(2), 79-100. https://doi.org/10.2478/cer-2014-0015

Zacharevič, G., \& Dzemyda, I. (2015). Global competitiveness of exporting business: the case study of Lithuania. Science: Future of Lithuania, 7(2), 253-261. 